\title{
Scientia Medica: impulsionando o círculo virtuoso
}

\author{
Scientia Medica: propelling the virtuous circle
}

Eleonor G. Lago

Editora

DESCRITORES: EDITORAÇÃO/tendências; POLÍTICAS EDITORIAIS; PUBLICAÇÕES CIENTÍFICAS.

KEY WORDS: PUBLISHING/trends; EDITORIAL POLICIES; SCIENTIFIC PUBLICATIONS.

Ao fecharmos o último fascículo do volume 24, constatamos que a Scientia Medica publicou 60 artigos em 2014, número que até então não vinha sendo alcançado. $\mathrm{O}$ aumento na quantidade de artigos publicados está principalmente relacionado ao número de artigos de boa qualidade submetidos, que vem crescendo paulatinamente. Com este número de artigos por ano, e considerando que mais de $60 \%$ são artigos originais, a Scientia Medica passa a cumprir com mais um dos critérios de qualidade considerados importantes pelas bases indexadoras, sendo este o único critério que até o ano anterior ainda não havia sido atingido.
Um dos fatores contribuintes para o maior aporte de bons artigos pode ter sido a evolução do Qualis Capes da revista no último triênio, que melhorou consideravelmente (Figura 1). Por outro lado, a evolução do Qualis é fruto da qualidade editorial, do conteúdo relevante que vem sendo publicado e da conquista de importantes bases indexadoras. Assim, impulsionado o círculo virtuoso dos periódicos científicos, a tendência é evoluir mais rapidamente para classificações e indexações ainda melhores.

Agradecemos aos autores e revisores de 2014 e desejamos aos leitores um excelente aproveitamento do material publicado.

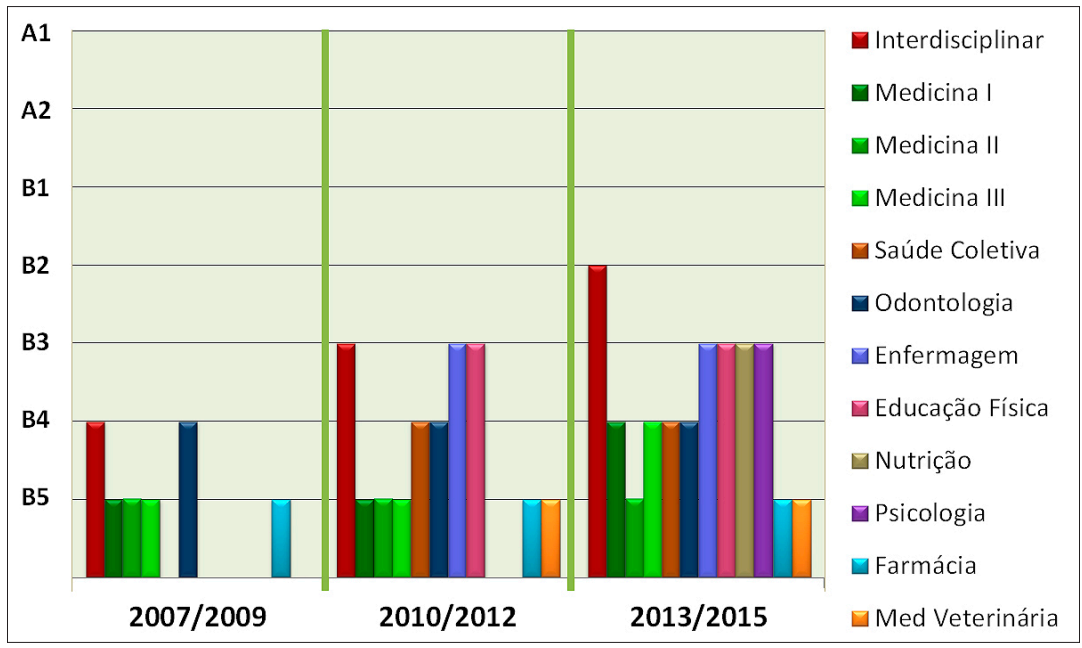

Figura 1. Evolução do Qualis Capes da Scientia Medica nos três últimos triênios. Cada coluna representa uma Área da Capes. Os espaços vazios referem-se a áreas que ainda não classificavam a revista nos triênios anteriores. 